\title{
Thermal Behavior of Insulation Fiberboards Made from MDF and Paper Wastes
}

\section{Toplinska svojstva izolacijskih vlaknatica izrađenih od otpadnog MDF-a i papira}

\author{
Original scientific paper • Izvorni znanstveni rad \\ Received-prispjelo: 14. 4. 2020. \\ Accepted-prihvaćeno: 26. 5. 2021. \\ UDK: $630 * 863.312 ; 630 * 863 * 31$ \\ https://doi.org/10.5552/drvind.2021.2019
}

(C) 2021 by the author(s). Licensee Faculty of Forestry and Wood Technology, University of Zagreb. This article is an open access article distributed under the terms and conditions of the Creative Commons Attribution (CC BY) license.

\begin{abstract}
Today, recycling is becoming increasingly important. In recycling process, the product performance should also be considered. In this study, manufacturing insulation fiberboard, as a practical wood product from recycled fibers, was investigated. For this purpose, two types of waste (MDF wastes and waste paper) were recycled to fibers and used for producing insulation fiberboards. The target fiberboard density was $0.3 \mathrm{~g} / \mathrm{cm}^{3}$. The ratio of waste paper to $M D F$ waste recycled fibers $(W P / R F)$ was considered at two levels of 70/30 and 50/50. Poly vinyl acetate adhesive was used as a variable in the board manufacturing process. The mechanical properties, dimensional stability, thermal conductivity, and fire resistance of the boards were evaluated. Besides, the thermal stability of fiberboards was studied using thermal analysis including thermogravimetric analysis (TGA) and differential thermal analysis (DTA). The results showed that the insulation fiberboards had admissible mechanical properties and dimensional stability. The manufactured boards displayed low thermal conductivity, which proved to be well competitive with other insulation materials. The fiberboards manufactured with PVAc adhesive and WP/ $R F$ ratio of 50/50 had higher fire resistance compared to other treatments. Additionally, results of thermal analysis showed that the use of PVAc adhesive and WP/RF ratio of 50/50 leads to improved thermal stability. Overall, the recycled fibers from $M D F$ and paper wastes appear to be appropriate raw materials for manufacturing thermal insulation panels, and use of PVAc adhesive can significantly improve thermal and practical properties of insulation fiberboards.
\end{abstract}

Keywords: insulation fiberboards; recycling; thermal stability; MDF wastes; waste paper

SAŽETAK • Danas recikliranje postaje sve važnije, a u tom postupku treba uzeti u obzir $i$ svojstva proizvoda koji se recikliranjem dobivaju. U ovom je radu istražena proizvodnja izolacijske ploče vlaknatice kao praktičnoga drvnog proizvoda od recikliranih vlakana. Za tu su namjenu u vlakna reciklirane dvije vrste otpada (MDF otpad $i$ papirni otpad), koje su iskorištene za proizvodnju izolacijskih ploča vlaknatica. Ciljana gustoća ploče vlaknatice bila je $0,3 \mathrm{~g} / \mathrm{cm}^{3}$. Planirani je omjer vlakana recikliranih od otpadnog papira i MDF otpada (WP/RF) iznosio 70 : 30 i 50 : 50. U procesu proizvodnje ploča upotrijebljeno je polivinilacetatno ljepilo. Eksperimentom su određena ova mehanička svojstva ploča: dimenzijska stabilnost, toplinska vodljivost $i$ vatrootpornost. Osim toga, uz pomoć toplinske analize koja je podrazumijevala termogravimetrijsku analizu (TGA) i diferencijalnu toplinsku analizu (DTA) istražena je toplinska stabilnost ploča vlaknatica. Rezultati su pokazali da izolacijske ploče vlaknatice imaju odgovarajuća mehanička svojstva i dimenzijsku stabilnost. Usto, proizvedene su ploče imale nisku toplinsku vodljivost, što potvrđuje njihovu konkurentnost s ostalim izolacijskim materijalima. Ploče vlaknatice proizvedene

\footnotetext{
Authors is assistant professor, University of Mohaghegh Ardabili, Faculty of Agriculture and Natural Resources, Ardabil, Iran.

2 Author is PhD graduated, University of Tehran, Faculty of Natural Resources, Tehran, Iran.
} 
s PVAc ljepilom i uz omjer WP/RF od $50: 50$ imale su veću vatrootpornost od ploča proizvedenih ostalim postupcima (omjerima sastojaka). Usto, rezultati toplinske analize pokazali su da upotreba PVAc ljepila i omjer WP/RF od 50 : 50 pridonose poboljšanoj toplinskoj stabilnosti. Zaključno, reciklirana vlakna od MDF otpada i otpadnog papira čine se prikladnom sirovinom za proizvodnju termoizolacijskih ploča, a uporaba PVAc ljepila može znatno poboljšati toplinska i uporabna svojstva takvih izolacijskih ploča vlaknatica.

Ključne riječi: izolacijske ploče vlaknatice; recikliranje; toplinska stabilnost; MDF otpad; otpadni papir

\section{INTRODUCTION}

\section{UVOD}

MDF (medium-density fiberboards) is known as one of the most essential raw materials for the construction and furniture industry (Pan et al., 2018). Due to the growing consumption of MDF, a huge amount of waste has been generated. Despite the well-known problems of toxic gas emissions to human health and environmental problems, in some countries, such as Iran, waste MDF is still burned, instead of being recycled. Due to the decline in the quality of MDF boards made from recycled fibers, manufacturers are reluctant to recycle this waste. The change in the chemical composition and the urea-formaldehyde resin residues on the surface of the recycled wood fibers leads to an increase in fiber pH. (Lykidis and Grigoriou, 2008; Medved and Resnik, 2004). Considering the incompatibility of the recycled fibers with urea-formaldehyde resin, one of the possible solutions could be to use the recycled fibers to produce binderless boards. Therefore, insulation fiberboard production is an additional alternative to add value to these materials. Insulation fiberboard is a free-formaldehyde, green material made of natural fibers with a low density between 0.1 to 0.35 $\mathrm{g} / \mathrm{cm}^{3}$. One of the most critical applications of insulation fiberboard could be its use as thermal insulator in buildings (Epinoza-Herrera and Cloutier, 2009). Due to climate change trends and the importance of reduced energy consumption, it is necessary to develop materials with high thermal insulation ability to sustain proper temperature in interior environments (Sable et al., 2015; Torres Rivas et al., 2018). The materials used as the building thermal insulation must have high specific heat capacity, low density, and low thermal conductivity (Pavelek and Adamova, 2019). Plastic foam and mineral wools are usually used as thermal insulation in building construction. Regarding the petroleum basis of plastic foam and health risks of mineral wools, it is necessary to find a safer and more environmentally friendly alternative for insulation purposes (Kawasaki and Kawai, 2006). Over the past years, raising awareness of environmental issues and harmful effect of chemicals on human health and other organisms have led to the development of green materials (Pavelek and Adamova, 2019). In the previous researches, agricultural and forestry wastes as the insulation materials have been investigated (Asdrubali et al., 2015; Lin et al., 2017; Tsalagkas et al., 2019). One of the important sources of natural fibers, which has not been given enough attention so far, is MDF wastes. However, the high flammability of the natural fibers restricted their applications (Cai et al., 2016). Thermal stability and fire -resistance of insulation materials is a necessary factor. TGA-DTA and fire retardant tests can be useful techniques to evaluate the performance of insulation materials. TGA measures the mass losses of materials under the influence of elevated temperatures, so it can partially simulate the thermal degradation occurring in fire events (Ramiah, 1970). In this study, the fiberboards were manufactured by a mixture of recycled fibers from MDF and paper wastes to achieve better formation of natural bonds. Waste paper, due to its large number of hydroxyl groups, allows natural bonds to be formed, thus contributing to better formation of fiberboard.

The aim of this study is to investigate the fiberboard produced from recycled fibers without chemicals, along with protecting the natural environment and sustainable use of resources.

\section{MATERIALS AND METHODS}

\section{MATERIJALI I METODE}

\subsection{MDF wastes recycling process}

2.1. Proces recikliranja MDF otpada

For this study, MDF wastes and original fibers were obtained from Pars Neopan MDF factory in Iran (Nashtarood). This factory uses a mixture of hardwoods as raw material. These wastes always remain after size cutting of produced MDF boards.

Poly vinyl acetate resin was supplied by Shomal Chemical Industry, a manufacturer of resins and adhesives. The properties of PVAc are shown in Table 1.

Table 1 Properties of PVAc resin Tablica 1. Svojstva PVAc smole

\begin{tabular}{|c|c|c|c|}
\hline $\begin{array}{c}\text { Solid Content, \% } \\
\text { Sadržaj suhe } \\
\text { tvari, \% }\end{array}$ & $\begin{array}{c}\text { Ash } \\
\text { Pepeo, \% }\end{array}$ & $\begin{array}{c}\text { Color } \\
\text { Boja }\end{array}$ & $\begin{array}{c}\text { Form } \\
\text { Oblik }\end{array}$ \\
\hline 40 & 0.2 & White / bijela & $\begin{array}{c}\text { Liquid / } \\
\text { tekućina }\end{array}$ \\
\hline
\end{tabular}

A laboratory chipper crushed the wastes of MDF, and then the chips were treated with hot water at $100{ }^{\circ} \mathrm{C}$ for $30 \mathrm{~min}$. After that, the wet chips and waste paper were transferred to the pulper, and the fibers were mechanically released.

\subsection{Process of manufacturing insulation fiberboards}

2.2. Proces proizvodnje izolacijskih ploča vlaknatica

Fibers and water were added to the mixture with a weight ratio of 0.03:1 (treatments with adhesive materials), and then $40 \mathrm{~g}$ PVAc solution was added to the mixture, too. The obtained pulp was poured to the forming 


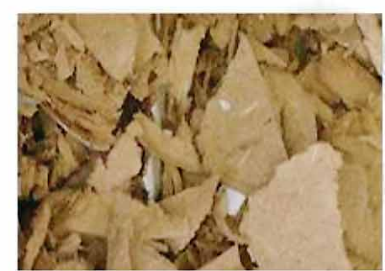

1-Chipping the MDF wastes

1-Usitnjavanje MDF otpada

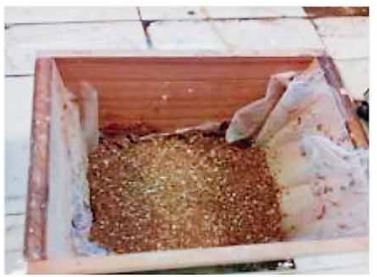

5-Forming

5-Formiranje

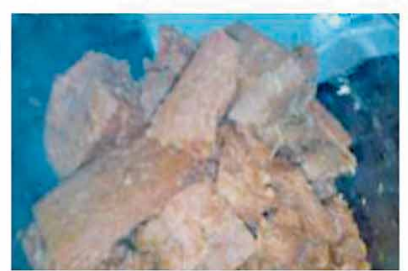

2-Treating the MDF wastes whit hot water

2-Tretiranje MDF otpada vrućom vodom

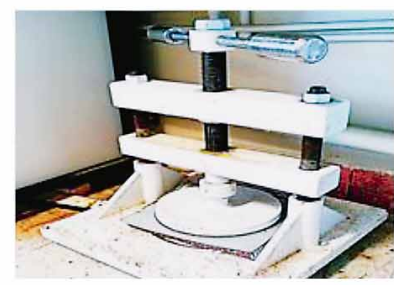

6-Cold pressing 6-Hladno prešanje

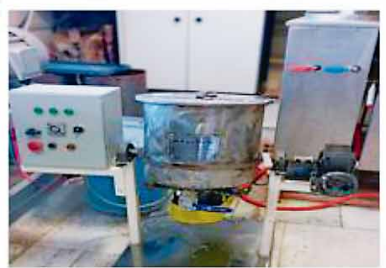

3-Pulping MDF and paper wastes

3-Priprema kaše od MDF otpada i otpadnog papira

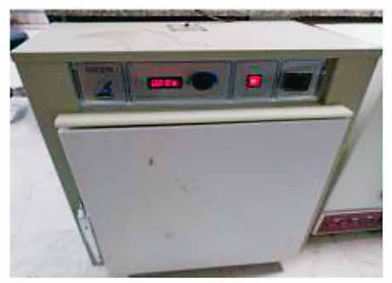

7-Drying in oven

7-Sušenje u sušioniku

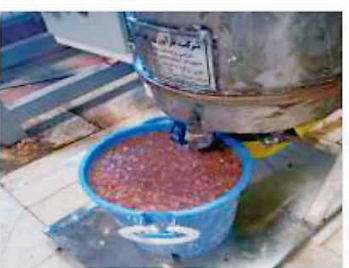

4-Mixing the fibers and PVAc with water

4-Miješanje vlakana i PVAc ljepila $s$ vodom

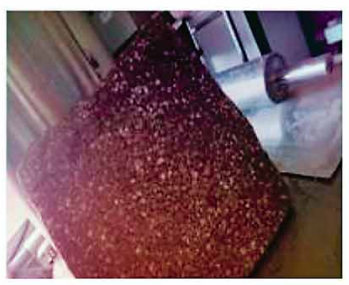

8-Final insulation fibreboard

8-Izolacijska ploča vlaknatica

Figure $1 \mathrm{MDF}$ wastes recycling and production process stages of insulation fiberboards

Slika 1. Recikliranje MDF otpada i proizvodni proces izolacijskih ploča vlaknatica

equipment, which let water draining, by gravity and low pressure of hand molding. At the end of this step, the thickness of the board reached 30 to $40 \mathrm{~mm}$. The board was pressed at 3.5 bar pressure to a final thickness of 12 $\mathrm{mm}$ in a cold press. Finally, the wet board was dried for $24 \mathrm{~h}$ at $100{ }^{\circ} \mathrm{C}$, then cooled, weighed and measured, and its density was calculated (the density of insulation fiberboards must be around $0.3 \mathrm{~g} / \mathrm{cm}^{3}$ ). The manufactured boards were conditioned at $20{ }^{\circ} \mathrm{C}$ and $65 \%$ humidity for two weeks before trimming to prepare test samples. The MDF wastes recycling and production process stages are shown in Figure 1.

\subsection{Morphology of fibers}

2.3. Morfologija vlakana

Franklin method was used for the separation of wood fibers to study the morphology of fibers. Specimens of virgin and recycled fibers were macerated in a mixture $(1: 1)$ of $30 \%$ hydrogen peroxide and acetic acid in a $64{ }^{\circ} \mathrm{C}$ oven for 24 hours. After maceration, the samples were washed with distilled water. For measuring fiber dimension, the microscopic images were captured by Motic microscope. After that, the fiber dimensions were measured in Image $\mathrm{j}$ software. The dimension of 50 fibers was measured for each kind of fibers.

\subsection{Physical and mechanical properties \\ 2.4. Fizička i mehanička svojstva}

Thickness swelling (TS) after immersion in water for $2 \mathrm{~h}$, modulus of rupture $(M O R)$, modulus of elasticity $(M O E)$ and internal bonding $(I B)$ were calculated according to JISA 5905:2003.

\subsubsection{Thickness swelling after immersion in water} 2.4.1. Debljinsko bubrenje nakon potapanja u vodi

First the thickness of the center part of the test piece shall be measured to the nearest $0.05 \mathrm{~mm}$ by a dial gauge or a micrometer, next the test piece shall be placed in water horizontally in depth of about $3 \mathrm{~cm}$ below the water surface at a temperature of $20 \pm 1{ }^{\circ} \mathrm{C}$. After immersion in water for $2 \mathrm{~h}$, the test piece shall be taken out of water, the water on the test piece shall be removed, and the swelling in thickness after immersion in water shall be calculated by Eq. 1:

$$
\begin{aligned}
& \text { Swelling in thickness after } \\
& \text { immersion in water }(\%)
\end{aligned}=\frac{t_{2}-t_{1}}{t_{1}} \cdot 100
$$

Where, $t_{1}$ - thickness of test piece before immersion (mm) $t_{2}$ - thickness of test piece after immersion ( $\left.\mathrm{mm}\right)$

\subsubsection{Bending strength}

\subsection{2. Čvrstoća na savijanje}

Using the test apparatus, as shown in Figure 2, a load of about $10 \mathrm{~mm} / \mathrm{min}$ at a mean deforming rate on the surface of test piece was applied. The maximum load $(P)$ shall be measured, and the bending strength shall be obtained from Eq. 2:

$$
\text { Bending strength }\left(\frac{N}{\mathrm{~mm}^{2}}\right)=\frac{3 \cdot P \cdot L}{2 \cdot b \cdot t^{2}}
$$

Where, $P$ - maximum load $(N)$

$$
\begin{aligned}
& L-\operatorname{span}(\mathrm{mm}) \\
& b-\text { width of test piece }(\mathrm{mm}) \\
& t \text { - thickness of test piece }(\mathrm{mm})
\end{aligned}
$$

\subsubsection{Internal bonding}

\subsection{3. Čvrstoća na raslojavanje}

The test piece shall be adhered to a steel block. The tensile load is applied vertically to the surface test

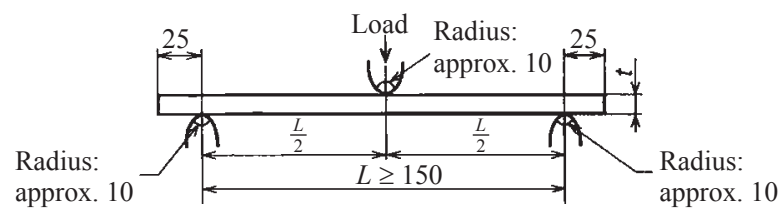

Figure 2 Bending strength test apparatus

Slika 2. Uređaj za ispitivanje čvrstoće na savijanje 
of the test piece, the maximum load $(P)$ at the time of the fracture of the adhesion part shall be measured, and the internal bond shall be calculated by Eq. 3:

$$
\text { Internal bond }\left(\frac{N}{m m^{2}}\right)=\frac{P}{b \cdot L}
$$

Where, $P$ - maximum load at time of fracture of adhesion part $(N)$

$b$ - width of sample ( $\mathrm{mm})$

$L$ - length of sample (mm)

\subsection{Thermal conductivity}

\subsection{Toplinska vodljivost}

Thermal conductivity coefficient $(\lambda)$ of the insulation fiberboards was measured across the thickness of the panel using a heat flux meter custom-made apparatus.

The full size of the specimens was $500 \mathrm{~mm} \times 500$ $\mathrm{mm}$ but heat flow was measured in the $120 \mathrm{~mm} \times 120$ mm midrange of the sample. The temperature difference between the hot and cold plate was set to $10{ }^{\circ} \mathrm{C}$. For each panel type, the thermal conductivity test was carried out on three specimens.

\subsection{Fire resistance}

\subsection{Vatrootpornost}

Fire resistance was assessed by the ignitability of products subjected to direct impingement of flame. The test procedure was performed according to STN EN ISO 11925-2:2010.

The test sample with a size of $170 \mathrm{~mm} \times 150 \mathrm{~mm}$ was exposed to a small flame with a height of $30 \mathrm{~mm}$ for a specified time. The burner must be inclined by an angle of $45^{\circ}$ to the vertical axis.

The flame is applied to the sample for $60 \mathrm{~s}$. The measured properties consisted of mass reduction, inflammation time, fire endurance and burnt area.

\subsection{Thermal stability analysis \\ 2.7. Analiza toplinske stabilnosti}

For investigating the thermal behavior of insulation fiberboards, Simultaneous Thermal Analysis (TGA/DTA) was done using Linseis Analyzer (STA PT 1000).

$10 \mathrm{mg}$ of each sample was placed on a balance located in the furnace, and heat was applied over the temperature range of room temperature to $600{ }^{\circ} \mathrm{C}$. The analysis was performed under a nitrogen atmosphere flowing at $20 \mathrm{~mL} / \mathrm{min}$ and a scanning rate of $20^{\circ} \mathrm{C} / \mathrm{min}$.

\subsection{Statistical analysis}

2.8. Statistička analiza

The effect of the recycled fiber proportion and the adhesive utilization on the properties of insulation fiberboards was assessed by one-way ANOVA statistical analysis. Also, Duncan's Multiple Range Test (DMRT) was used to check for significant differences between treatment groups.

\section{RESULTS AND DISCUSSION}

3. REZULTATI I RASPRAVA

\subsection{Morphology of fibers}

\subsection{Morfologija vlakana}

The appearance of virgin and recycled fibers is shown in Figure 3. It is obvious that recycled fibers have been damaged as compared to virgin fibers. Fiber degradation occurs due to the pressure and high temperature applied to the fibers during the process of making the initial boards, gluing step, loss of wood polymers, heating and mechanical recycling operations (Lykidis and Grigoriou, 2008).

The measured values of length and diameter of the fibers are presented in Table 2. The results showed that the length and especially the diameter of recycled fibers are less than those of virgin fibers due to the destruction of fibers in the initial board manufacturing and recycling process. The length of the fibers plays an important role in the physical and mechanical properties and its reduction leads to a decrease in the quality of the manufactured boards (Dix et al., 2001a).

\subsection{Physical and mechanical properties of insulation fiberboards}

3.2. Fizička i mehanička svojstva izolacijskih ploča vlaknatica

Statistical analysis of physical and mechanical properties is summarized in Table 3.

Table 2 Morphology of virgin and recycled fibers Tablica 2. Morfologija djevičanskih i recikliranih vlakana

\begin{tabular}{|c|c|c|}
\hline Fibers / Vlakna & $\begin{array}{c}\text { Length, } \mathbf{~ m m} \\
\text { Duljina, } \mathbf{m m}\end{array}$ & $\begin{array}{c}\text { Diameter, } \mathbf{m m} \\
\text { Promjer, } \mathbf{m m}\end{array}$ \\
\hline $\begin{array}{c}\text { Virgin fibers } \\
\text { djevičanska vlakna }\end{array}$ & 2.8 & 0.52 \\
\hline $\begin{array}{c}\text { Recycled fibers } \\
\text { reciklirana vlakna }\end{array}$ & 1.62 & 0.33 \\
\hline
\end{tabular}

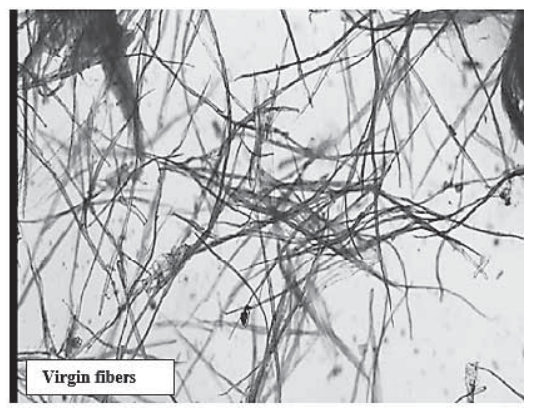

Figure 3 Appearance of virgin and recycled fiber surface (unit mm, magnification 40x)

Slika 3. Izgled površine djevičanskih i recikliranih vlakana (jedinica: mm, povećanje: 40 puta) 
Table 3 Statistical analysis of physical and mechanical properties of insulation fiberboard produced with different treatments ( $T S$ - thickness swelling, $M O R$ - modulus of rupture, $M O E$ - modulus of elasticity, $I B$ - internal bonding)

Tablica 3. Statistička analiza fizičkih i mehaničkih svojstava izolacijskih ploča vlaknatica proizvedenih različitim tretmanima (TS - debljinsko bubrenje, $M O R$ - modul loma, $M O E$ - modul elastičnosti, IB - čvrstoća na raslojavanje)

\begin{tabular}{|l|l|c|c|c|}
\hline Properties / Svojstva & Variables / Varijable & $\begin{array}{c}\text { Mean square } \\
\text { Srednji kvadrat }\end{array}$ & $\begin{array}{c}\text { df (within groups) } \\
d f \text { (unutar grupa) }\end{array}$ & sign. \\
\hline \multirow{4}{*}{$T S, \%$} & Proportion of fibers / udio vlakana & 29.67 & 1 & 0.000 \\
\cline { 2 - 5 } & Adhesive utilization / uporaba ljepila & 48.15 & 1 & 0.000 \\
\cline { 2 - 5 } & Interaction effect / međudjelovanje & 8.56 & 1 & 0.008 \\
\hline \multirow{3}{*}{ MOR, MPa } & Proportion of fibers / udio vlakana & 41.19 & 1 & 0.000 \\
\cline { 2 - 5 } & Adhesive utilization / uporaba ljepila & 373.71 & 1 & 0.000 \\
\cline { 2 - 5 } & Interaction effect / međudjelovanje & 2.839 & 1 & 0.001 \\
\hline \multirow{3}{*}{ IBOE, MPa } & Proportion of fibers / udio vlakana & 1970114.01 & 1 & 0.000 \\
\cline { 2 - 5 } & Adhesive utilization / uporaba ljepila & 1153714.08 & 1 & 0.000 \\
\cline { 2 - 5 } & Interaction effect / međudjelovanje & 148632.73 & 1 & 0.000 \\
\hline & Proportion of fibers / udio vlakana & 0.432 & 1 & 0.000 \\
\cline { 2 - 5 } & Adhesive utilization / uporaba ljepila & 0.98 & 1 & 0.000 \\
\cline { 2 - 5 } & Interaction effect / međudjelovanje & 0.09 & 1 & 0.000 \\
\hline
\end{tabular}

The analysis showed that the effect of different ratios of fibers and adhesive utilization on both physical and mechanical properties of insulation fiberboards was significant at a $99 \%$ confidence interval (Sig $<0.01$ ). Duncan's multiple range classification of the effect of different treatments is shown in Table 4.

As shown in Table 4, instead of thickness swelling of the insulation fiberboards, which is better than values defined in the standard, the other measured properties are lower than those specified in the standard, but they are relatively acceptable regarding their low density and manufacturing condition (without synthetic resin and hot pressing). The application of the manufactured fiberboards is restricted; they are intended to be used as insulator, and they cannot be used in applications where high strength is required. The use of PVAc adhesive resulted in the improvement of the physical and mechanical properties of insulation fiberboards. PVAc can improve the adhesion of fibers (Sable et al., 2015). PVAc, as an insulator, provides not only mechanical strength but also prevents the exposure of fibers to the atmosphere and leads to high stability in the environment (Hosseini and Entezami, 2005). In terms of thickness swelling and internal bonding, WP/RF ratio of 50/50 is suggested. However, considering $M O R$ and $M O E, \mathrm{WP} / \mathrm{RF}$ ratio of $70 / 30$ leads to better results due to more flexibility of waste paper as compared to fibers recycled from MDF wastes, which is the result of a lower amount of lignin and decreased stiffness of waste paper. As the results show, an increased amount of waste paper leads to a decrease in the internal bonding of boards because of heterogeneous forming of boards, which results in a lack of proper bonding between the different components of two types of fiber (Rassam, 2008). Paper fibers also have a higher specific surface area than that of wood fibers because of their small size and high slenderness ratio, which results in better absorption of the adhesive and prevents uniform spreading between the fibers. Because of this phenomenon, the internal adhesion of boards with a higher proportion of waste paper is reduced (Ghahri, 2017). Each type of fiber has its own unique characteristics due to their different preparation methods. Considering MDF fibers, hemicelluloses and lignin of the intercellular material have been partially degraded, also due to the mechanical method of fiber separation, fractures occurred in the fibers and the dissolved lignin resulted in fusion and reconnection of the fibers in hot press (Ghahri, 2017). However, in the case of paper fibers, chemical and semi-chemical pulping have a profound effect on cellulose fibers and cell walls. These include the removal of large amounts of hemicelluloses and lignin from the reticular cell walls and their conversion into larger pores reticular

Table 4 Average values of Duncan's multiple range classification of the effect of different treatments on properties of produced insulation fiberboards: N-70-30 (without adhesive, WP/RF ratio of 70/30), N-50-50 (without adhesive, WP/RF ratio of 50/50), W-70-30(with PVAc adhesive, WP/RF ratio of 70/30) and W-50-50 (with PVAc adhesive, WP/RF ratio of 50/50)

Tablica 4. Srednje vrijednosti Duncanove višestruke klasifikacije učinka različitih tretmana na svojstva proizvedenih izolacijskih ploča vlaknatica: N-70-30 (bez ljepila, omjer WP/RF $70: 30$ ), N-50-50 (bez ljepila, WP/RF omjer $50: 50$ ), W-70-30 (s PVAc ljepilom, WP/RF omjer $70: 30$ ) i W-50-50 (s PVAc ljepilom, WP/RF omjer $50: 50$ )

\begin{tabular}{|l|c|c|c|c|c|}
\hline $\begin{array}{l}\text { Property } \\
\text { Svojstvo }\end{array}$ & $\mathbf{N - 7 0 - 3 0}$ & $\mathbf{N - 5 0 - 5 0}$ & $\mathbf{W - 7 0 - 3 0}$ & $\mathbf{W - 5 0 - 5 0}$ & $\begin{array}{c}\text { Standard values } \\
\text { (Thickness of 12 to 19 mm) } \\
\text { Standardne vrijednosti } \\
\text { (debljina od 12 do 19 mm) }\end{array}$ \\
\hline$T S, \%$ & $10.17(\mathrm{~b})$ & $6.88(\mathrm{ab})$ & $7.46(\mathrm{ab})$ & $6.12(\mathrm{a})$ & 12 \\
\hline$M O R, \mathrm{MPa}$ & $18(\mathrm{c})$ & $11(\mathrm{~d})$ & $19.5(\mathrm{~b})$ & $13.7(\mathrm{a})$ & 20 \\
\hline$M O E, \mathrm{MPa}$ & $1520.66(\mathrm{~b})$ & $1034.11(\mathrm{c})$ & $1860.01(\mathrm{a})$ & $1630.49(\mathrm{~b})$ & 2200 \\
\hline$I B, \mathrm{MPa}$ & $0.09(\mathrm{~b})$ & $0.099(\mathrm{~b})$ & $0.209(\mathrm{~b})$ & $0.41(\mathrm{a})$ & 0.55 \\
\hline
\end{tabular}


system that creates space and locality for water absorption. The partial removal of lignin and hemicellulose polymers results in the availability of large numbers of hydroxyl groups in the cell wall of the fibers, which leads to excellent hydrogen bonding of the fibers and subsequently dimensional stability of the produced fiberboards. Waste paper fibers and recycled fibers from MDF wastes have different morphology. The waste paper fibers lose much lignin, while the recovered fibers from MDF wastes have more lignin, which makes them stiffer as compared to paper fibers (Hwang et al., 2005). When the combination of paper fibers and recycled fibers from MDF wastes are used for fiberboard manufacturing, inter-fiber bonds are formed better.In addition, the paper fibers have a bearded state due to refining operations, which makes them more likely to have hydrogen bonds (Rassam, 2008).

\subsection{Thermal conductivity of insulation fiberboards} 3.3. Toplinska vodljivost izolacijskih ploča vlaknatica

Thermal conductivity is an indicator of the value of a material as a heat insulator (Xu et al., 2004). Wood based panels manufacturing methods, wood based materials and wood particle sizes were indicated as having a large effect on thermal conductivity (Tsalagakas et al., 2019). As it can be observed in Figure 4, the insulation fiberboards made from PVAc adhesive and the $\mathrm{WP} / \mathrm{RF}$ ratio of $50 / 50$ is a better insulator compared to other treatments. The use of PVAc decreased thermal conductivity.

Utilization of waste paper and fibers recycled from MDF wastes as a component appears to be an appropriate choice for manufacturing insulation fiberboards. Paper has been employed as insulation material due to its low thermal conductivity value. The thermal conductivity of paper varies upon the paper sheet density, filler content, nature of fibers, etc. (Tsalagakas et al., 2019). The measured thermal conductivity ( of the obtained boards was within the interval of 0.025-0.037 $\mathrm{W} / \mathrm{m} \cdot \mathrm{K}$, which is in the range of building bio-based insulation materials (Theasy et al., 2017). Due to the different structure of the two types of fibers (obtained from waste paper and MDF wastes) and process of manufacturing, the structure of the insulation fiberboards is very porous. Low thermal conductivity of the insulation fiberboards is due to the low conductivity of the air trapped in the pores. The large number of spaces and voids inside the insulators impeded heat transfer, resulting in considerably lower thermal conductivity (Sihabut and Laemsak, 2010). The thermal conductivity of air is lower than that of solid materials (Nguyen et al., 2018). For better comparison, the measured values of for different kinds of insulators, according to the results reported by other researchers, are presented in Table 5.

\subsection{Fire resistance of insulation fiberboards}

3.4. Vatrootpornost izolacijskih ploča vlaknatica

According to Table 6, samples lose their weight about $3 \%$ to $15 \%$ of the weight of the initial value after $60 \mathrm{~s}$ of flame exposure.

The results of flame resistance values of insulation fiberboards showed that the lowest mass reduction was related to fiberboards manufactured with PVAc adhesive and WP/RF ratio of 50/50 (lower amount of paper), which can confirm the positive effect of the use of adhesive on the thermal stability of insulation fiberboards. It is obvious that the use of PVAc can increase the fire resistance of insulation boards. PVAc is degraded by elimination of acetic acid, yielding a char that provides a transitory phase as the filler particles fuse into a ceramic mass (Al-hassany et al., 2010). Insulation fiberboards manufactured without adhesive and $\mathrm{WP} / \mathrm{RF}$ ratio of $50 / 50(\mathrm{~N}-50-50)$ had the lowest ther-

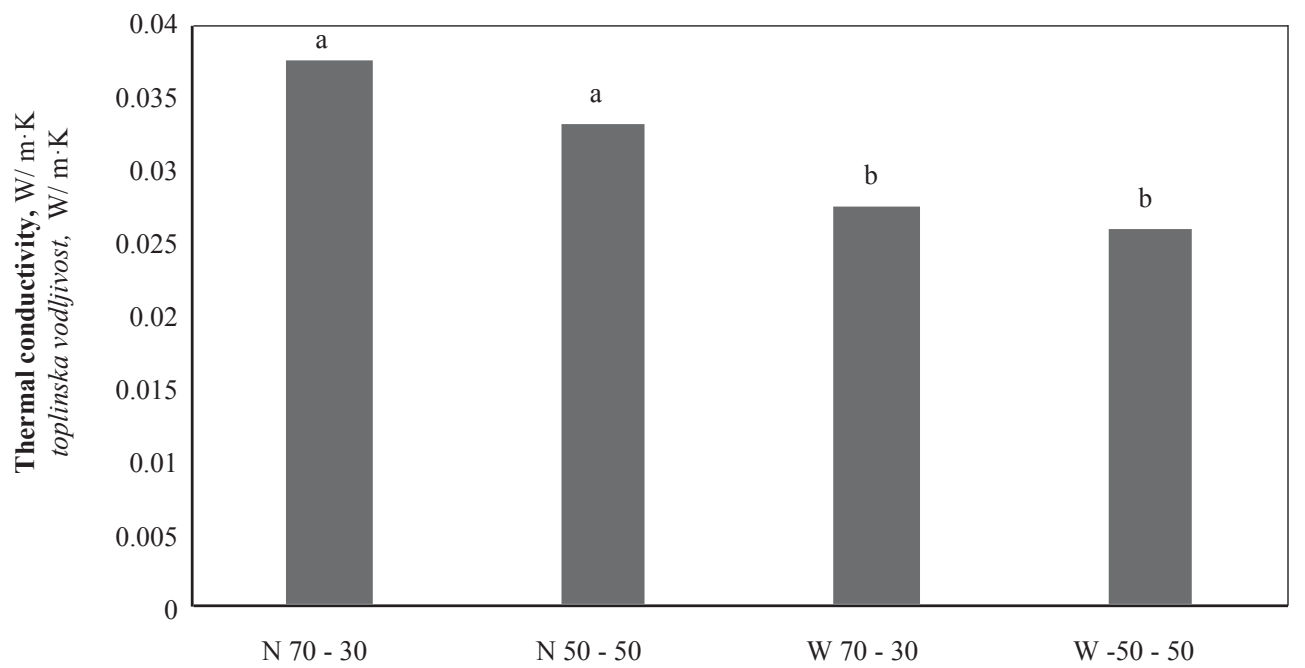

Figure 4 Thermal conductivity values of insulation fiberboards made by different treatments (Duncan's multiple range classifications are shown above the columns: N-70-30 (without adhesive, WP/RF ratio of 70/30), N-50-50 (without adhesive, $\mathrm{WP} / \mathrm{RF}$ ratio of 50/50), W-70-30(with PVAc adhesive, WP/RF ratio of 70/30) and W-50-50 (with PVAc adhesive, WP/RF ratio of 50/50)

Slika 4. Vrijednosti toplinske vodljivosti izolacijskih ploča vlaknatica izrađenih različitim tretmanima (Duncanove višestruke klasifikacije prikazane su iznad stupaca): N-70-30 (bez ljepila, omjer WP/RF 70 : 30), N-50-50 (bez ljepila, omjer WP/RF 50 : 50), W-70-30 (s PVAc ljepilom, omjer WP/RF 70 : 30) i W-50-50 (s PVAc ljepilom, omjer WP/RF 50 : 50) 
Table 5 Thermal conductivity of different kinds of insulators

Tablica 5. Toplinska vodljivost različitih vrsta izolacijskog materijala

\begin{tabular}{|c|c|c|}
\hline Material / Materijal & $\begin{array}{c}\text { Thermal conductivity } \\
\text { coefficient, } \mathbf{W} / \mathbf{m} \cdot \mathbf{K} \\
\text { Koeficijent toplinske } \\
\text { vodljivosti, } \mathrm{W} / \mathrm{m} \cdot \mathrm{K} \\
\end{array}$ & Literature / Literatura \\
\hline Wood with density of 0.45 to $0.65 \mathrm{~g} / \mathrm{cm}^{3} /$ drvo gustoće $0,45-0,65 \mathrm{~g} / \mathrm{cm}^{3}$ & 0.13 & Xu et al., 2004 \\
\hline Wood with density of 0.2 to $0.5 \mathrm{~g} / \mathrm{cm}^{3} /$ drvo gustoće $0,2-0,5 \mathrm{~g} / \mathrm{cm}^{3}$ & 0.01 & Kawasaki and Kawai, 2006 \\
\hline Plywood with density of $1.7 \mathrm{~g} / \mathrm{cm}^{3} /$ furnirska ploča gustoće $1,7 \mathrm{~g} / \mathrm{cm}^{3}$ & 0.071 & Xu et al., 2004 \\
\hline $\begin{array}{l}\text { Insulation board with density of } 0.26 \mathrm{~g} / \mathrm{cm}^{3} \\
\text { izolacijska ploča gustoće } 0,26 \mathrm{~g} / \mathrm{cm}^{3}\end{array}$ & 0.044 & Xu et al., 2004 \\
\hline Concrete with density of $0.2 \mathrm{~g} / \mathrm{cm}^{3} /$ cement gustoće $0,2 \mathrm{~g} / \mathrm{cm}^{3}$ & 1.2 & Xu et al., 2004 \\
\hline Bricks with density of $1.7 \mathrm{~g} / \mathrm{cm}^{3} /$ cigla gustoće $1,7 \mathrm{~g} / \mathrm{cm}^{3}$ & 0.53 & Xu et al., 2004 \\
\hline Waste paper / otpadni papir & $0.05-0.06$ & Tsalagakas et al., 2019 \\
\hline $\begin{array}{l}\text { Waste newspaper particle board } \\
\text { iverica od otpadnoga novinskog papira }\end{array}$ & 0.025 & Theasy et al., 2017 \\
\hline $\begin{array}{l}\text { Insulation boards from oil palm fronds } \\
\text { izolacijske ploče od palminih listova }\end{array}$ & 0.034 & Sihabut and Laemsak, 2010 \\
\hline $\begin{array}{l}\text { Insulation boards from empty fruit branches } \\
\text { izolacijske ploče na bazi grana voćaka }\end{array}$ & 0.038 & Sihabut and Laemsak, 2010 \\
\hline Rock wool / kamena vuna & 0.037 & Sihabut and Laemsak, 2010 \\
\hline $\begin{array}{l}\text { Bark based panels from popular } \\
\text { ploče na bazi kore topolovine }\end{array}$ & $0.069-0.093$ & Tsalagakas et al., 2019 \\
\hline $\begin{array}{l}\text { Wooden matts from wood shaving and kenaf fibers } \\
\text { drveni tepisi na bazi blanjevine } i \text { vlakana od kenafa }\end{array}$ & 0.069 & Tsalagakas et al., 2019 \\
\hline
\end{tabular}

Table 6 Average values of fire resistance properties of insulation fiber boards and Duncan's multiple range classification of the effect of different treatments: N-70-30 (without adhesive, WP/RF ratio of 70/30), N-50-50 (without adhesive, WP/RF ratio of 50/50), W-70-30(with PVAc adhesive, WP/RF ratio of 70/30) and W-50-50 (with PVAc adhesive, WP/RF ratio of $50 / 50)$

Tablica 6. Srednje vrijednosti svojstava vatrootpornosti izolacijskih ploča vlaknatica i Duncanova višestruka klasifikacija učinka različitih tretmana: N-70-30 (bez ljepila, omjer WP/RF $70: 30$ ), N-50-50 (bez ljepila, omjer WP/RF 50 : 50), W-70-30 (s PVAc ljepilom, omjer WP/RF 70 : 30) i W-50-50 (s PVAc ljepilom, omjer WP/RF $50: 50$ )

\begin{tabular}{|l|c|c|c|c|}
\hline Property / Svojstvo & N-70-30 & N-50-50 & W-70-30 & W-50-50 \\
\hline Mass reduction, \% / smanjenje mase, \% & $7.44(\mathrm{c})$ & $15.21(\mathrm{~d})$ & $4.71(\mathrm{~b})$ & $2.62(\mathrm{a})$ \\
\hline Inflammation time, s / vrijeme zapaljenja, $\mathrm{s}$ & $5(\mathrm{a})$ & $2(\mathrm{a})$ & $9(\mathrm{~b})$ & $8(\mathrm{~b})$ \\
\hline Fire endurance, s / vatrootpornost, $\mathrm{s}$ & $75(\mathrm{~b})$ & $120(\mathrm{c})$ & $15(\mathrm{a})$ & $10(\mathrm{a})$ \\
\hline Burnt area, \% / izgorjela površina, $\%$ & $21(\mathrm{~b})$ & $38(\mathrm{c})$ & $4(\mathrm{a})$ & $1(\mathrm{a})$ \\
\hline
\end{tabular}

mal stability as compared to other treatments due to low internal bonding and weakness in bonding formation. Reducing internal bonding between fibers and the fuzzy surface of boards caused more surface burns and lead to an increased mass reduction of the boards, which is an important criterion for assessing fire resistance of boars (Hojati et al., 2018).

\subsection{Thermal stability of insulation fiberboards}

3.5. Toplinska stabilnost izolacijskih ploča vlaknatica

Figures 5 and 6 show the TGA-DTG and DTA curves of insulation fiberboards, respectively.

Thermal degradation mechanism of wood occurred in three regions, including $60-100{ }^{\circ} \mathrm{C}$ (evaporation of water and extractives), $130-350{ }^{\circ} \mathrm{C}$ (decomposition of major wood chemical constituents) and after $350{ }^{\circ} \mathrm{C}$ (complete decomposition of wood) (Feng et al., 2012; Bodirlau et al., 2009; Yunchu et al., 2000). Above $200{ }^{\circ} \mathrm{C}$, the pyrolysis speed increases, hemicelluloses and cellulose decompose into gases (Yunchu et al., 2000). In a temperature range between (250 to 300 ${ }^{\circ} \mathrm{C}$, lignin and cellulose are degraded, and tar, gas and char are produced during the pyrolysis (Hakiki- Uner et al., 2016). After heating to $350{ }^{\circ} \mathrm{C}$, since the amount of flammable gas is very small, the flame burn transforms into the flameless charcoal burn. In this step, weight loss slows down (Yunchu et al., 2000). After $430{ }^{\circ} \mathrm{C}$, an exothermal peak of wood burn appears on the DTA curve (Figure 6).

Instead of the N-70-30 curve, which is related to insulation fiberboards made by WP/RF ratio of 70/30 and without adhesive, in other curves, the sharp exothermal peak is smoothed and the temperature of the peak is increased. This means that the utilization of a higher amount of wood fibers and adhesive increased the thermal stability of fiberboards, and the rates of heat released slowly down. The broadest peak is related to W-50-50 insulation fiberboards, which are manufactured by the use of PVAc adhesive and a lower amount of waste paper. Concerning the N-70-30 curve, the main component is waste paper. Waste paper is mainly composed of cellulose. The shape of this curve and the intensity of the decomposition peak are very similar to those of the cellulose curve (Sobol et al., 2020). In fact, there is a larger share of cellulose in this sample and therefore its shape is different from other 

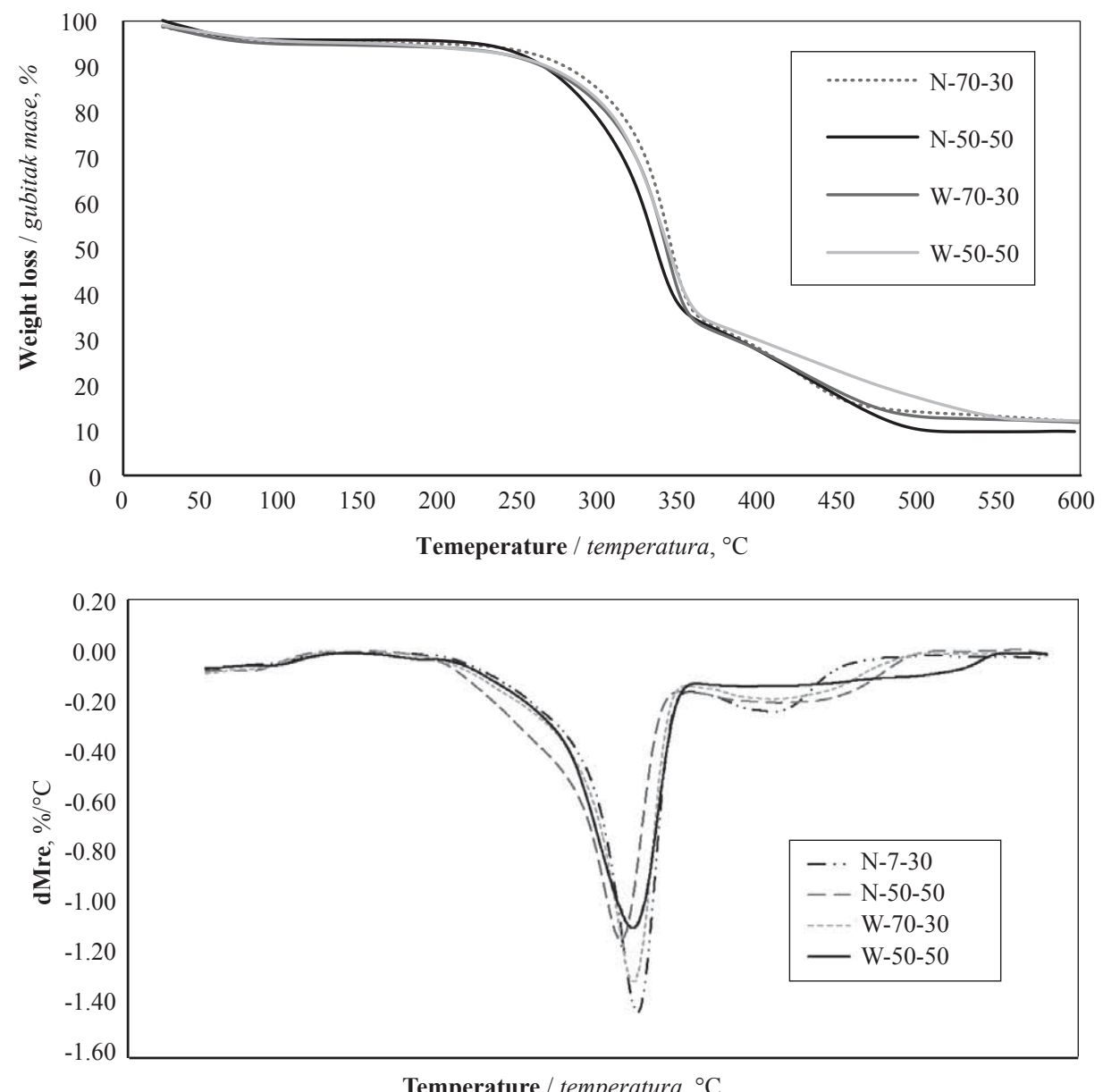

Figure 5 TGA-DTG thermograms of insulation fiberboards: N-70-30 (without adhesive, WP/RF ratio of 70/30), N-50-50 (without adhesive, WP/RF ratio of 50/50), W-70-30 (with PVAc adhesive, WP/RF ratio of 70/30) and W-50-50 (with PVAc adhesive, WP/RF ratio of 50/50)

Slika 5. TGA-DTG termogrami izolacijskih ploča vlaknatica: N-70-30 (bez ljepila, omjer WP/RF 70 : 30), N-50-50 (bez ljepila, omjer WP/RF 50 : 50), W-70-30 (s PVAc ljepilom, omjer WP/RF 70 : 30) i W-50-50 (s PVAc ljepilom, omjer WP/RF 50 : 50)

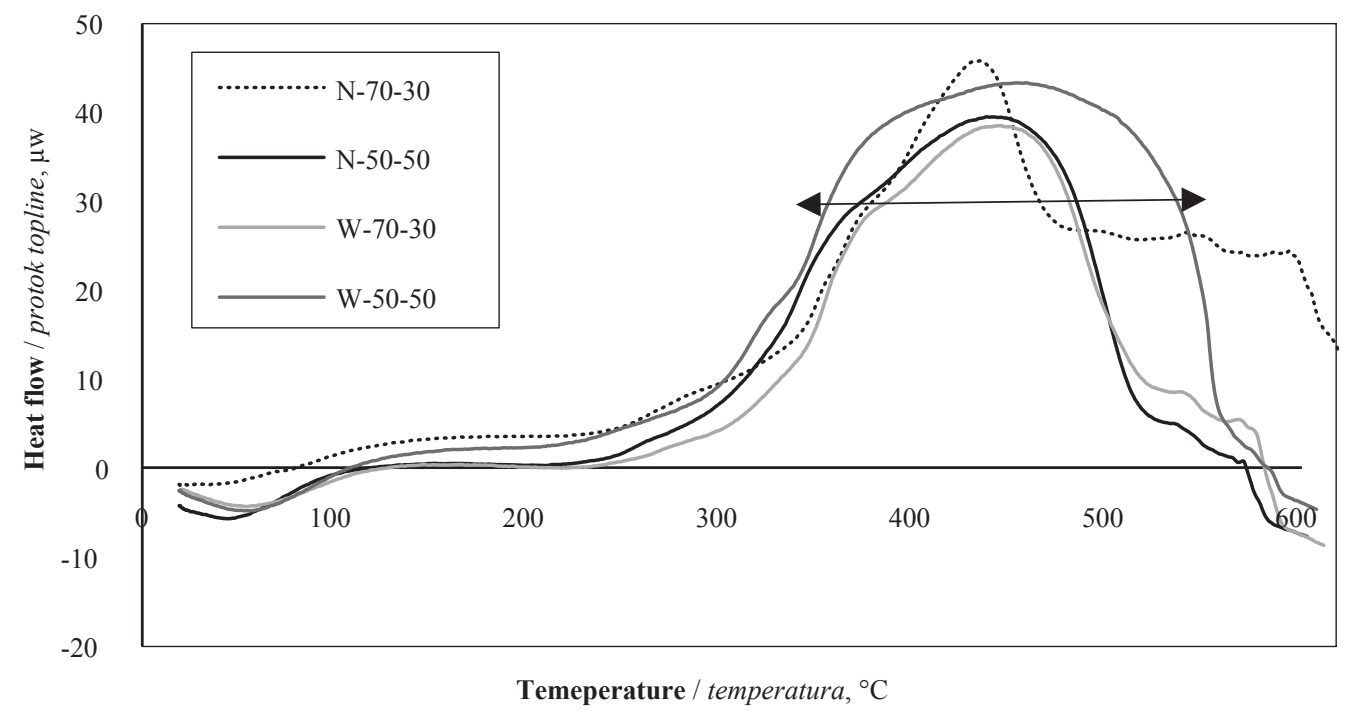

Figure 6 DTA thermograms of insulation fiberboards: N-70-30 (without adhesive, WP/RF ratio of 70/30), N-50-50 (without adhesive, WP/RF ratio of 50/50), W-70-30 (with PVAc adhesive, WP/RF ratio of 70/30) and W-50-50 (with PVAc adhesive, $\mathrm{WP} / \mathrm{RF}$ ratio of $50 / 50)$

Slika 6. DTA termogrami izolacijskih ploča vlaknatica: N-70-30 (bez ljepila, omjer WP/RF 70 : 30), N-50-50 (bez ljepila, omjer WP/RF 50 : 50), W-70-30 (s PVAc ljepilom, omjer WP/RF 70 : 30) i W-50-50 (s PVAc ljepilom, omjer WP/RF 50 : 50) 
Table 7 TGA - DTA results from insulation fiberboards manufactured by waste MDF and paper fibers: N-70-30 (without adhesive, WP/RF ratio of 70/30), N-50-50 (without adhesive, WP/RF ratio of 50/50), W-70-30(with PVAc adhesive, WP/RF ratio of 70/30) and W-50-50 (with PVAc adhesive, WP/RF ratio of 50/50)

Tablica 7. TGA - DTA rezultati za izolacijske ploče vlaknatice proizvedene od vlakana MDF otpada i otpadnog papira: N-70-30 (bez ljepila, omjer WP/RF $70: 30$ ), N-50-50 (bez ljepila, omjer WP/RF 50 : 50), W-70-30 (s PVAc ljepilom, omjer WP/RF 70 : 30) i W-50-50 (s PVAc ljepilom, omjer WP/RF 50 : 50)

\begin{tabular}{|c|c|c|c|c|c|c|c|}
\hline $\begin{array}{c}\text { Samples } \\
\text { Uzorci }\end{array}$ & $\boldsymbol{T}_{\mathbf{i}}-\boldsymbol{T}_{\mathbf{r}},{ }^{\circ} \mathbf{C}$ & $\boldsymbol{T}_{\mathbf{m}},{ }^{\circ} \mathbf{C}$ & $\boldsymbol{W}_{\mathrm{Ti}}, \boldsymbol{\%}$ & $\begin{array}{c}\boldsymbol{W}_{\max } \mathbf{\%} \\
\text { (second region / } \\
\text { drugo područje) }\end{array}$ & $\boldsymbol{W}_{\mathrm{Tr}}, \boldsymbol{\%}$ & $\begin{array}{c}\text { Residues, \% } \\
\text { Ostatak, } \%\end{array}$ & DTA peak, ${ }^{\circ} \mathbf{C}$ \\
\hline N-70-30 & $105.7-470$ & 359.9 & 3.23 & 60.21 & 23.22 & 11.8 & 432 \\
\hline N-50-50 & $100.3-500$ & 355.4 & 4.16 & 59.21 & 26.94 & 9.7 & 445 \\
\hline W-70-30 & $134.8-490$ & 363.8 & 4.13 & 61.58 & 21.49 & 11.7 & 450 \\
\hline W-50-50 & $125.5-550$ & 358.3 & 3.79 & 20.21 & 22.86 & 12 & 460 \\
\hline
\end{tabular}

$T_{\mathrm{i}}-T_{\mathrm{f}}$ - temperature corresponding to the beginning and end of decomposition, respectively / temperatura koja odgovara početku $i$ kraju razgradnje; $T_{\mathrm{m}}$ - Temperature corresponding to the maximum rate of mass loss / temperatura koja odgovara najvećem gubitku mase; $W$ weight loss / gubitak mase

curves. Summary data of TGA-DTA for fibers can be observed in Table 7.

The results show that the degradation began faster with insulation fiberboard in which PVAc adhesive was used. In addition, when the lower percentage of waste paper was used, the degradation reaction occurred faster. $T_{m}$ as a crucial factor, was higher with insulation fiberboards made from WP/RF ratio of 70/30 with PVAc and lower with insulation fiberboards manufactured without adhesive and WP/RF ratio of 50/50. The maximum weight loss was observed in insulation fiberboard manufactured with PVAc adhesive and WP/ $\mathrm{RF}$ ratio of 70/30. The lowest weight loss with a significant difference occurred in insulation fiberboards manufactured with PVAc adhesive and WP/RF ratio of 50/50 (W-50-50). The higher weight loss means lower thermal stability (Aydemir et al., 2011). It can be said that the use of adhesive and a lower percentage of waste paper results in a higher thermal stability. There is not a significant difference in terminal mass residues of different treatments. The lowest mass residue (9.7 $\%$ ) was observed with insulation fiberboard manufactured without adhesive and with $50 \%$ waste paper, the reason probably being the weak bonding of this kind of board. Overall, it can be concluded that the use of adhesive results in increased thermal stability of insulation fiberboard. Also, the higher amount of waste paper decreased the thermal stability of insulation fiberboards. DTA peak temperature in N-70-30 fiberboards was significantly lower than in other treatments, which confirmed previously obtained results and showed that this treatment caused lower thermal stability of fiberboards. The thermal resistance of a compound is related to the breakdown of the weakest bond at a specific temperature as the temperature was raised (Bachari, 2015).

\section{CONCLUSIONS}

\section{ZAKLJUČAK}

This study showed that it is possible to manufacture insulation fiberboard from wastes of MDF and paper by the wet process.

According to the measured values, which were similar to mineral wool, it can be said that the manu- factured insulation fiberboards can be properly used as a structural insulator.

The use of PVAc adhesive and a lower percentage of waste paper (WP/RF ratio of 50/50) in manufacturing fiberboard result in a higher fire resistance and thermal stability, in better functional properties and lower thermal conductivity values of insulation fiberboards.

Better insulators have better thermal stability.

Overall, it can be concluded that waste MDF and paper have good potential to be used as raw material for producing green insulation fiberboards. with better results obtained from treatment in which PVAc adhesive and the WP/RF ratio of 50-50 (waste paper to recycled MDF fibers) were used.

\section{REFERENCES}

\section{LITERATURA}

1. Al-Hassany, Z.; Genoves, A.; Shanks, R., 2010: Fire-retardant and fire-barrier poly(vinyl acetate) composites for sealant application. Polymer Letters, 4 (2): 79-93.

2. Asdrubali, F.; D’Alessandro, F.; Schiavoni, S.; 2015: A review of unconventional sustainable building insulation materials. Sustainable Materials and Technologies, 4: 1-17. https://doi.org/10.1016/j.susma t.2015.05.002.

3. Aydemir, D.; Gunduz, G.; Altuntas, E.; Ertas, M.; Turgut, S.; Alma, H., 2011: Investigating changes in the chemical constituents and dimensional stability of heat- treated Hornbeam and Uludag Fir wood. BioResources, 6 (2): 13081321. https://doi.org/10.15376/biores.6.2.1308-1321.

4. Bachari, T. H., 2015: Thermal properties of polyvinyl acetate and toluene diisocyanate with prepared sulfonated phenol-formaldehyde resin as composites. Basrah Journal of Science (A), 33 (1): 4769.

5. Bodirlau, R.; Teaca, C. A.; Spiridon, I., 2009: Preparation and characterization of composites comprising modified hardwood and wood polymers/poly(vinyl chloride). BioResources, 4 (4): 1285-1304. https://doi.org/10.15376/ biores.4.4.1285-1304.

6. Cai, H.; Zhung, B.; Huwang, D.; Wang, W.; Nih, M.; Xie, Y.; Chen, T.; Wang, X., 2016: Ultra low-density fiberboard with improved fire retardance and thermal stability using a novel fire-resistant adhesive. BioResources, 11 (2): 5215:5229.

https://doi.org/10.15376/biores.11.2.5215-5229.

7. Dix, B.; Schafer, M.; Roffael, E., 2001a: Using fibers from waste fiberboards pulped by a thermo-chemical 
process to produce medium density fiberboard (MDF). Holz als Roh und Werkstoff, 59 (4): 276.

8. Epinoza-Herrera, R.; Cloutier, A., 2009: Thermal degradation and thermal conductivity of gypsum-cement particleboard. Wood and Fiber Science, 41 (1): 13-21.

9. Feng, Y.; Mu, J.; Chen, S. H.; Huang, Z. H.; Yu, Z. H., 2012: The influence of urea formaldehyde resins on pyrolysis characteristics and products of wood based panels. Bioresources Journal, 7 (4): 4600-4613. https://doi.org/10.15376/biores.7.4.4600-4613.

10. Franklin, G. L., 1945: Properties of thin sections of synthetic resins and wood-resin composites, and a new macerating method for wood. Nature, 155 (3924): 51-59.

11. Ghahri, S., 2017: Soy flour adhesive modification by tannic acid and its application in boards made from recycled old corrugated containers (OCC) and wood fibers. PhD Thesis, Tarbiat Moddares University, Iran.

12. Hakiki-Uner, I.; Deveci, I.; Baysal, E.; Turkay, T.; Toker, H.; Peker, H., 2016: Thermal analysis of oriented beech wood treated with some borates as fire retardants. Maderas Ciencia Y Tecnologia, 18 (2): 293-304. https://doi.org/10.4067/S0718-221X2016005000027.

13. Hojati, E.; Daday Ghandi, S.; Enayati, A. A.; Rashedi, K., 2013: Effect of basilit on fire resistance and physical and mechanical properties of high-density fiberboard. Journal Of Forest And Wood Products, 66 (3): 319-328.

14. Hosseini, S. H.; Entezami, A., 2005: Studies of thermal and electrical conductivity behaviors of polyaniline and polypyrrole blends with polyvinyl acetate, polystyrene, and poly vinyl chloride. Iranian Polymer Journal, 14 (3): 201-209.

15. Hwang, C. Y.; Hse, C. R.; Shupe, T. F., 2005: Effects of recycled fiber on the properties of fiberboard panels. Forest Product Journal, 55 (11): 61-64.

16. Kawasaki, T.; Kawai, S., 2006: Thermal insulation properties of the wood-based sandwich panel for use as structural insulated walls and floors. Journal of Wood Science, 52: 75-83. https://doi.org/10.1007/s10086-005-0720-0.

17. Liu, L. F.; Li, H. Q.; Lazzaretto, A.; Manente, G.; Tong, C. Y.; Liu, G. B.; Li, N. P., 2017: The development history and prospects of biomass-based insulation materials for buildings. Renew Sustain Energy Review, 69: 912932. https://doi.org/10.1016/j.rser.2016.11.140.

18. Lykidis, C.; Grigoriou, A., 2008: Hydrothermal recycling of waste and performance of the recycled wooden particleboards. Waste Management, 28: 57-63. https://doi. org/10.1016/j.wasman.2006.11.016.

19. Mevdad, S.; Resnik, J., 2004: Influence of the acidity and size of beech particles on the hardening of the urea formaldehyde adhesive. Acta Chimica Slovenica, 51: 353360 .

20. Nguyena, D. M.; Grilleta, A.; Diepb, T. M. H.; Buia, Q. B.; Woloszyna, M., 2018: Influence of thermo-pressing conditions on insulation materials from bamboo fibers and proteins based bone glue. Industrial Crops \& Products, 111: 834-845.

21. Pan, L.; Jiang, Y.; Wang, L.; Xu, W., 2018: Kinetic study on the pyrolysis of medium density fiberboard: effects of secondary charring reactions. Energies, 11: 2481: 1-17. https://doi.org/10.3390/en11092481.
22. Pavelek, M.; Adamova, T., 2019: Bio-waste thermal insulation panel for sustainable building construction in steady and unsteady state conditions. Materials, 12: 1-17. https://doi.org/10.3390/ma12122004.

23. Ramiah, M. V., 1970: Thermogravimetric and differential thermal analysis of cellulose, hemicellulose and lignin. Journal of Applied Polymer Science, 14 (5): 1323 1337. https://doi.org/10.1002/app.1970.070140518.

24. Rassam, G., 2008: Use of Soy/PF resin for the old corrugated container (OCC)- wood composites, Materials Letters, 62: 3236-3239. https://doi.org/10.1016/j.matlet.2008.02.030.

25. Sable, I.; Grinfelds, U.; Vikele, L.; Rozenberga, L.; Zeps, M.; Luguza, S., 2015: Thermal insulation from hardwood residues. IOP Conference Seriees, Materials Science and Engineering, 96: 1-7. https://doi.org/10.1088/1757899x/96/1/012027.

26. Sihabut, T.; Laemsak, N., 2010: Feasibility of producing insulation boards from oil palm fronds and empty Fruit bunches. Songklanakarin Journal of Science and Technology, 32 (1): 63-69.

27. Sobole, K. H.; Solodryy, S.; Petrovska, N.; Belov, S.; Hunyak, O.; Hidei, V., 2020: Chemical composition and hydraulic properties of incenerated waste paper sludge. Chemistry \& Chemical Technology, 14 (4): 538-544.

28. Theasy,Y.; +Yulianto, A.; Astuti, B., 2017: Effect of thickness on thermal conductivity based on waste newspaper particle bord. Journal of Natural Sciences and Mathematic Researches, 3 (1): 210-214.

29. Torres-Rivas, A.; Palumbo, M.; Haddad, A.; Cabeza, L. F.; Jiménez, L.; Boer, D., 2018: Multi-objective optimization of bio-based thermal insulation materials in building envelopes considering condensation risk. Applied Energy, 224: 602-614. https://doi.org/10.1016/j.apenergy.2018.04.079.

30. Tsalagkas, D.; Borcsoc, D.; Pasztory, Z., 2019: Thermal, physical and mechanical properties of surface overlaid bark-based insulation panels. European Journal of Wood and Wood Products, 77: 721-730. https://doi.org/10.1007/s00107-019-01436-5.

31. Xu, J.; Sugawara, R.; Widyorini, R.; Han, G.; Kawai, S. H., 2004: Manufacture and properties of low density binderless particle board from kenaf core. Journal of Wood Science, 50: 62-67. https://doi.org/10.1007/s10086-003-0522-1.

32. Yunchu, H.; Peijang, Z.; Songsheng, Q., 2000: TG-DTA Studies on wood treated with flame retardants. Holz als Roh und Werkstoff, 58: 35-38. https://doi.org/10.1007/s001070050382.

\section{Corresponding address:}

\section{Assist. Prof. BITA MOEZZIPOUR}

University of Mohaghegh Ardabili

Faculty of Agriculture and Natural Resources

Ardabil, IRAN

e-mail: b.moezzipour@uma.ac.ir 